\title{
Magnetostratigraphic confirmation of a much faster tempo for sea-level change for the Middle Triassic Latemar platform carbonates
}

\author{
Dennis V. Kent ${ }^{\mathrm{a}, \mathrm{b}, *}$, Giovanni Muttoni ${ }^{\mathrm{c}}$, Peter Brack ${ }^{\mathrm{d}}$ \\ ${ }^{a}$ Department of Geological Sciences, Rutgers University, Route 9W, Piscataway, NJ 08854-8066, USA \\ ${ }^{\mathrm{b}}$ Lamont-Doherty Earth Observatory, Palisades, NY 10964, USA \\ ${ }^{\mathrm{c}}$ Dipartimento di Scienze della Terra, Università di Milano, via Mangiagalli 34, I-20133 Milan, Italy \\ ${ }^{\mathrm{d} D e p a r t e m e n t ~ E r d w i s s e n s c h a f t e n, ~ E T H-Z e n t r u m, ~ C H-8092 ~ Z u ̈ r i c h, ~ S w i t z e r l a n d ~}$
}

Received 7 January 2004; received in revised form 12 October 2004; accepted 13 October 2004

Available online 18 November 2004

Editor: E. Boyle

\begin{abstract}
New magnetostratigraphic data for the $\sim 470$-m-thick Latemar carbonate platform, which includes $\sim 600$ shallowing-upward bedding cycles, are consistent with litho- and biostratigraphic correlations of the section to a $\sim 10$-m-thick interval in the basinal Buchenstein Beds that most likely represents only $\sim 1$ m.y. of deposition according to published U-Pb single-crystal zircon dates. A reappraisal of reported cycle stratigraphic analyses of the Latemar suggests that the visibly obvious meter-scale bedding is not due to Milankovitch precessional forcing but rather reflects tempos an order of magnitude faster that may involve millennial-scale tidal amplitude variations.
\end{abstract}

(C) 2004 Elsevier B.V. All rights reserved.

Keywords: Triassic; magnetostratigraphy; Latemar; platform carbonates; tidal forcing

\section{The Latemar controversy}

The Latemar is a $\sim 2.5$-km-diameter atoll-like carbonate platform cropping out in the Dolomites of northern Italy [1,2] (Fig. 1a). It formed during the

* Corresponding author. Department of Geological Sciences, Rutgers University, Piscataway, NJ 08854-8066, USA. Tel.: +1 845 365 8544; fax: +1 8453658158 .

E-mail address: dvk@rci.rutgers.edu (D.V. Kent).
Middle Triassic in the tropical western Tethys on the northern margin of Adria [3] (Fig. 1b). The platform interior is characterized by a $\sim 470$-m-thick lagoonal succession consisting of $\sim 600$ shallowing-upward cycles [4]. This cyclic succession, comprised of the Lower Cyclic Facies (LCF), Middle Tepee Facies (MTF), Upper Cyclic Facies (UCF), and Upper Tepee Facies (UTF) sensu [5], was attributed to a 9-12 m.y. record of precessional forcing of sea level change $[6,7]$. However, $\mathrm{U}-\mathrm{Pb}$ dating of zircons from volcanoclastic 


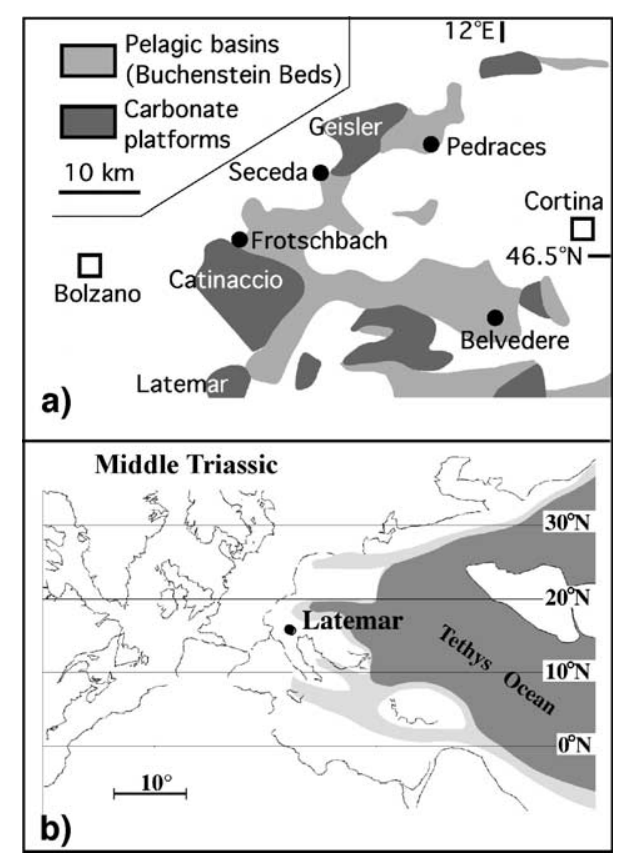

Fig. 1. (a) Distribution of Middle Triassic carbonate platform and basinal sediments in the Dolomites [2]. (b) Paleogeographic location of the Latemar platform in the Middle Triassic [27].

layers within the Latemar succession and the correlative basinal Buchenstein Beds suggests that the $\sim 600$ Latemar cycles instead span only up to a few million years $[2,8,9]$. The application of two sophisticated modern techniques to measure geologic time-astrochronology and $\mathrm{U}-\mathrm{Pb}$ single-crystal zircon datingthus leads to age estimates of Latemar carbonate platform deposition that differ by about one order of magnitude.

The stratigraphic framework of what has become known as the 'Latemar controversy' [10] is illustrated in Fig. 2 and can be outlined as follows. Talus/slope sediments of the Latemar platform interfinger with basinal deposits of the Anisian-Ladinian (Middle Triassic) Buchenstein Beds [5]. The interfingering of equivalent platform carbonates is well documented for the neighboring Rosengarten platform [11]. In the Buchenstein Beds, the stratigraphic interval corresponding to the entire platform interior portion at Latemar most likely spans the Lower Plattenkalke to the lower Knollenkalke of late Reitzi Zone to early Curionii Zone age [12]. In the Seceda core, this stratigraphic interval of the Buchenstein Beds is no more than about $15 \mathrm{~m}$ thick [13]. The inferred biostratigraphic assignment is supported by fossil data directly from the Latemar succession. The Chieseiceras ammonoid (L5) fauna from the uppermost preserved UTF and the Latemarites ammonoid (L1) fauna from just below the LCF indicate that the $\sim 470$ $\mathrm{m}$-thick lagoonal succession, which contains the $\sim 600$ shallowing-upward cycles, encompasses an interval from the late Reitzi Zone to the earliest Curionii Zone and thus bracketing the Secedensis Zone [9,10]. This biostratigraphic interval, which corresponds to only slightly more than one ammonoid (Secedensis) Zone, is less than $10 \mathrm{~m}$ thick in the Buchenstein Beds at Seceda.

An age model based on $\mathrm{U}-\mathrm{Pb}$ single-zircon dates from a series of volcanoclastic layers [2,8] suggests that the $\sim 6$ - to 8-m-thick Secedensis Zone in the Buchenstein Beds sections of the western Dolomites encompasses less than 1 m.y. (Fig. 2) and consequently had accumulated at a rate of about $10 \mathrm{~m} / \mathrm{m} . \mathrm{y}$. [12]. A similar duration has been estimated directly for the Latemar deposits based on $\mathrm{U}-\mathrm{Pb}$ single-zircon ages from three volcanoclastic layers found within the Latemar succession [9], indicating an overall sediment accumulation rate of $\sim 500 \mathrm{~m} / \mathrm{m}$.y. for the Latemar platform. This rate may seem high for Mesozoic platform carbonates but is within the range of rates for carbonate sedimentation and estimated growth potential of tropical and mud-mound carbonate factories scaled for a $10^{5}-10^{6}$ year time span of observation $[14,15]$.

In contrast, a recent cycle stratigraphic analysis was used to derive a duration of 3.1 m.y. for just a 160 -m-thick portion of the Latemar [7]. This is equivalent to a sediment accumulation rate of only $\sim 50 \mathrm{~m} / \mathrm{m}$.y. and implies a very long time span ( $\sim 9$ m.y.) for the entire 470-m-thick rhythmic Latemar succession. The low sedimentation rate-long time span interpretation also falls within the scaled range of carbonate production $[14,15]$ and accordingly, cannot be excluded on this general basis. However, according to this interpretation, the basin equivalent of the Latemar would have to be extremely condensed, with a sediment accumulation rate of as little as $\sim 1 \mathrm{~m} / \mathrm{m}$.y. [16]. This would imply that magnetozone $\mathrm{SC} 2 \mathrm{n}$ in the Seceda core [13], which is within the interval that can be correlated litho-biostratigraphically to the Latemar succession (Fig. 2), must represent an anomalously long polarity chron in the Triassic, a period in which 


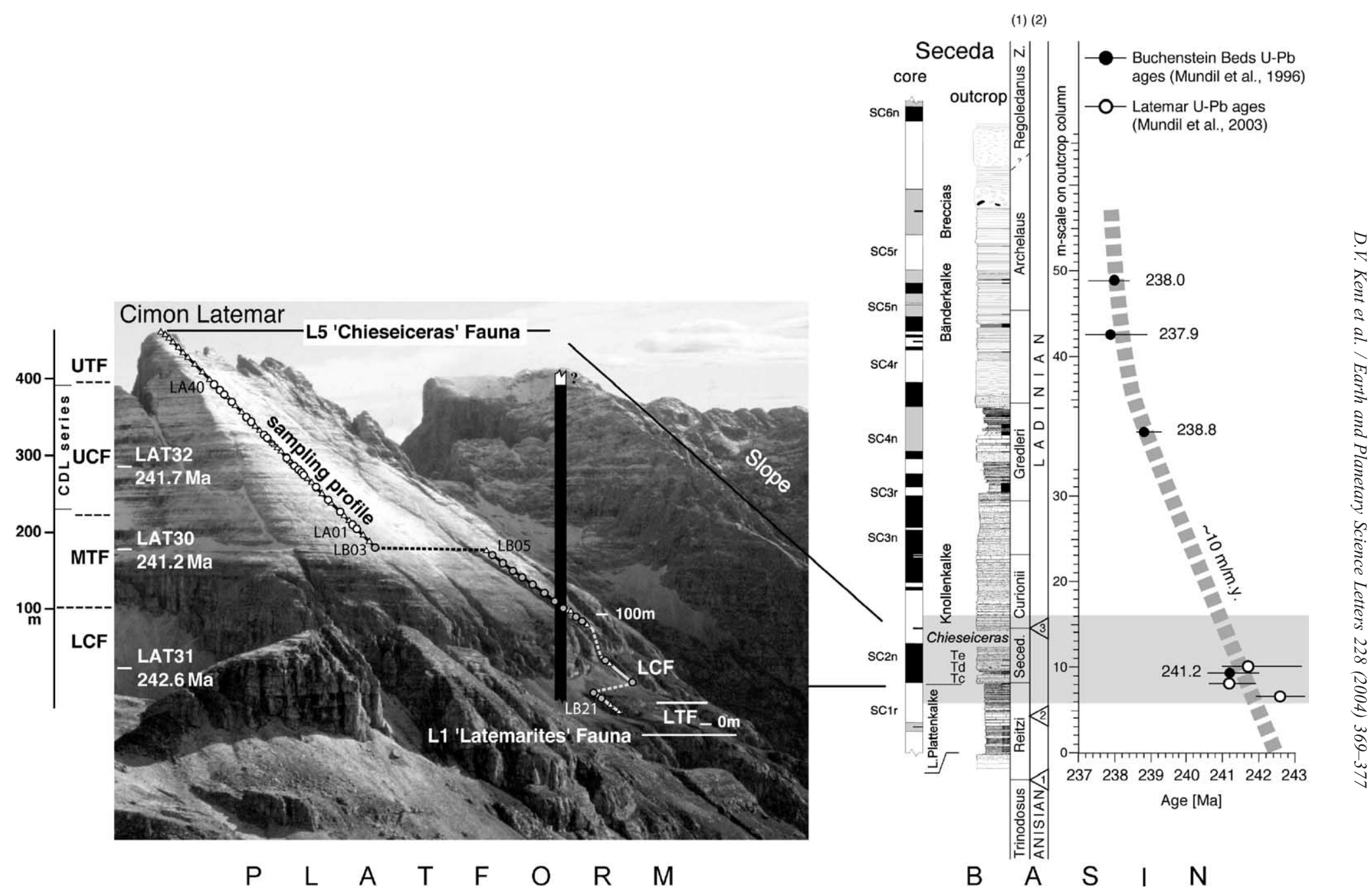

Fig. 2. Magneto-biostratigraphic correlation of the $\sim 470$-m-thick Latemar succession (thickness scale and subdivision after Ref. [10]) comprising $\sim 600$ shallowing-upward cycles [6] to the basinal Buchenstein Beds sediments at Seceda [13]. "CDL series" is the stratigraphic interval of the Cimon del Latemar section analyzed by Preto et al. [7]. Circles on sampling profile are levels that gave acceptable paleomagnetic results for magnetic polarity stratigraphy (solid/open bar, normal/reverse polarity) whereas triangles are samples rejected due to anomalously high magnetizations attributed to lightning strikes. For basin stratigraphy, column labeled (1) shows ammonoid zones, column (2) shows current candidates for AnisianLadinian boundary, m-scale explained in Ref. [13]. 
polarity interval lengths average only about $0.5 \mathrm{~m} . \mathrm{y}$. (e.g., see compilation in [17]).

We present magnetostratigraphic data from the Latemar lagoonal succession to test the association of the Secedensis Zone with a normal polarity interval (Chron SC2n) that is observed in the Buchenstein Beds [13] and to evaluate the polarity data in terms of other records of geomagnetic reversal frequency for the Triassic. We show that the magnetic polarity data are inconsistent with a long duration of the Latemar succession and offer an alternative interpretation of the Latemar cyclic stratigraphy in terms of Milankovitch and millennial-scale sea-level variations.

\section{Paleomagnetic data}

We collected 73 oriented samples with a portable rock-drill that were distributed from the base of the LCF to the top of Cimon Latemar in the UTF (Fig. 2). The samples have a low, carbonate-dominated diamagnetic susceptibility but according to isothermal remanent magnetization (IRM) experiments [18] on representative samples, contain a small ferrimagnetic fraction dominated by a moderate-coercivity, $\sim 570{ }^{\circ} \mathrm{C}$ maximum unblocking temperature phase attributable to magnetite. Progressive thermal demagnetization of the natural remanent magnetization (NRM) reveals two types of component structure in different samples. The NRMs of about a half of the samples have intensities $<0.1 \times 10^{-6} \mathrm{Am}^{2} / \mathrm{kg}$ and usually consist of an initial component that is removed by around $300{ }^{\circ} \mathrm{C}$ that generally conforms to a present-day field viscous overprint, followed by a stable component that converges to the origin by around $500{ }^{\circ} \mathrm{C}$ with a direction systematically oriented northwest and down (e.g., Fig. 3a, sample LA16). The other samples, which

Fig. 3. (a) Representative thermal demagnetization data of a sample (left) with NRM intensity $<0.1 \times 10^{-6} \mathrm{Am}^{2} / \mathrm{kg}$ and stable component directions systematically yielding normal polarity VGP latitudes, and a sample (right) with NRM intensity $>0.1 \times 10^{-6} \mathrm{Am}^{2} / \mathrm{kg}$ and stable component directions yielding nonsystematic, lighting-contaminated VGP latitudes. (b) VGP latitude versus NRM intensity showing that samples with NRM $>0.1 \times 10^{-6} \mathrm{Am}^{2} / \mathrm{kg}$ tend to have scattered VGP latitudes attributable to effects of lightning. (c) VGP latitude versus stratigraphic sample level of lightning-free (-) and lightingcontaminated stable magnetization components $(\mathrm{O})$. a)
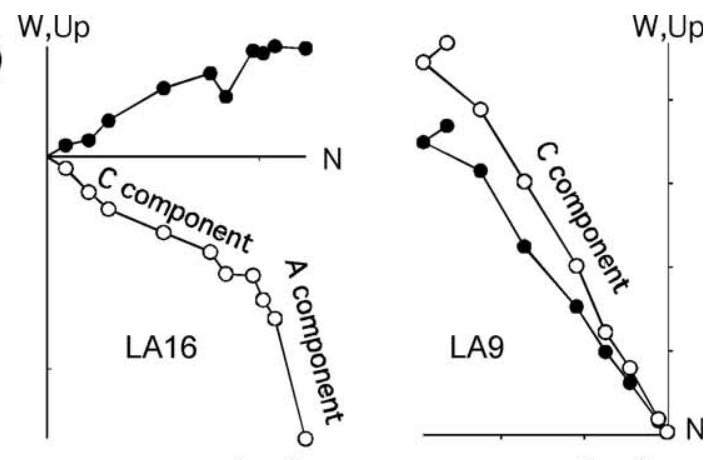

$\mathrm{NRM}=0.07 \times 10^{-6} \mathrm{Am}^{2} / \mathrm{kg}$

b)

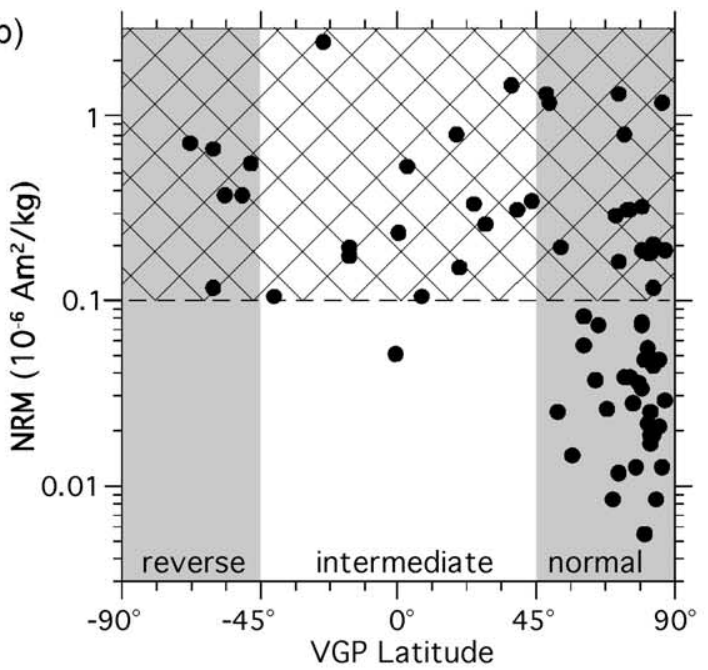

c)




are characterized by anomalously high NRM intensities $\left(>0.1 \times 10^{-6} \mathrm{Am}^{2} / \mathrm{kg}\right)$, are less frequently associated with a present-day field component and are often dominated by stable univectorial magnetizations that have no systematic orientation from sample to sample (e.g., Fig. 3a, sample LA9). In some samples in both groups, particularly those with the high NRM intensity, there may also be an initial component that is erratic in orientation rather than along the present-day field direction.

The erratic and strong magnetization components of NRM were most probably induced by high magnetic fields associated with modern lightning strikes, which are likely to have occurred on the exposed southern slope of Cimon Latemar where we unavoidably had to sample. IRM acquisitions $(2.5 \mathrm{~T})$ on a subset of sample chips show that samples with high NRM intensities are invariably associated with high NRM/IRM ratios $(>0.02)$, consistent with lightning-induced magnetizations rather than simply higher magnetic mineral concentrations being responsible for the anomalously high NRM intensities. A strong, univectorial NRM would be attributed to the most recent and proximal lightning strike that completely remagnetized the sample whereas the occasional presence of an additional erratic initial component direction might be due to variable resetting by lightning on more than one occasion. Erratic initial component directions that are also occasionally present in the more weakly magnetized samples are presumed to represent only partial resetting of the NRM by lightning and allow the recovery of the characteristic component.

Bearing this in mind, stable (high unblocking temperature) directions were chosen from Zijderveld orthogonal projections and estimated using standard least-squares line fitting; 70 samples provided acceptably well-defined stable directions. The corresponding virtual geomagnetic pole (VGP) and its latitude with respect to the mean Middle Triassic reference pole for Adria [19] were then calculated for each sample stable direction for analysis. Many of the sample VGP latitudes fall near the north paleopole, signifying normal polarity, a few fall closer to the south paleopole and an appreciable number have intermediate values more than $45^{\circ}$ from either end of the paleopole axis (Fig. 3b). However, the vast majority of the southerly and intermediate VGP latitudes correspond to those samples with anomalously high NRM intensity, which we attribute to effects of lightning.

To minimize lightning-induced spurious components from the sample population, we restricted our analysis to samples with lower NRM intensities, choosing $0.1 \times 10^{-6} \mathrm{Am}^{2} / \mathrm{kg}$ as a reasonable cutoff. The 33 samples satisfying this criterion provide a much clearer stratigraphic distribution of VGP latitudes, indicating that most of the Latemar succession has normal polarity with a suggestion of reverse polarity in the uppermost UCF (Fig 3c). The filtered mean direction $\left(\mathrm{Dec}=331^{\circ}, \mathrm{Inc}=32^{\circ}, \mathrm{a} 95=7^{\circ}, k=15\right.$, $N=33)$ is virtually the same as the mean paleomagnetic direction $\left(\mathrm{Dec}=332^{\circ}, \mathrm{Inc}=32^{\circ}, \mathrm{a} 95=4^{\circ}, k=6\right.$, $N=211$ ) obtained on pretilt magnetizations for the Buchenstein Beds from the Seceda core $[12,13]$.

\section{Magnetostratigraphic correlation}

The paleomagnetic data indicate that most of the Latemar succession is of normal magnetic polarity with tentative evidence of reverse polarity toward the top of the section. Effects of lightning complicate the picture but we believe that they can be satisfactorily recognized and filtered from the data set. In the absence of a fold or other field test, which was not possible in these flat-lying sediments, we cannot exclude the possibility that what we regard as the original characteristic component may in fact be an overprint acquired, for example, during the emplacement of dykes related to the nearby intrusions of Predazzo-Monzoni (see geologic map by Vardabasso [20]). A U-Pb date of $237.3+0.4 /-1.0$ Ma has been established on zircons from granites, which are among the youngest intrusive rocks at Predazzo [21]. However, the Latemar is not in direct contact with the main thermal aureole of the Predazzo intrusions and we avoided sampling in the proximity of the dikes that occur in the Latemar. Our sampling profile, with the possible exception of its lowermost part, was also well outside the area thought to be affected by dolomitizing hydrothermal fluids [22]. We therefore regard the magnetostratigraphic signature of the Latemar as representing the polarity of the paleomagnetic field during deposition.

The predominant normal polarity of the Latemar is consistent with deposition during Chron $\mathrm{SC} 2 \mathrm{n}$ that 
closely coincides with the Secedensis Zone and the interval of lithostratigraphic correlation with the Latemar in the Buchenstein Beds (Fig. 2). The following observations can be used to place broad but independent constraints on the maximum duration of this interval: (1) The entire Middle Triassic (Anisian and Ladinian) is no more than about 14 m.y. long [23] and may be considerably shorter, e.g., [24]. (2) No significant normal polarity bias or anomalously low reversal frequency has been documented for the Middle Triassic in global paleomagnetic compilations $[17,25,26]$. (3) Detailed magnetostratigraphic results from sections in Greece, Austria, Bulgaria, and Albania show that the Middle Triassic in fact includes at least 25 polarity intervals (see [27], and references therein). (4) In stratigraphic records in different sedimentary environments but with biostratigraphic constraints on intervals corresponding to the Secedensis Zone (e.g., Epidaurus/Greece: [28], and confirmed by our own observations; Humbolt Range/Nevada: [29], and personal communication from $\mathrm{H}$. Bucher), there is no evidence for anomalously long equivalents of the Secedensis Zone.

We conclude that Chron SC2n and the Secedensis Zone, which occupy only a small fraction of the Middle Triassic, cannot be anywhere near as long as 9-12 m.y. implied by the cycle stratigraphic analyses of the Latemar by Hinnov et al. [6,7]. In fact, a duration about an order of magnitude less ( 1 m.y.) for Chron SC2n and the Secedensis Zone that derives from a straightforward interpretation of the $\mathrm{U}-\mathrm{Pb}$ age model for Buchenstein deposition is compatible with all the other age constraints with the notable exception of the cycle stratigraphic analyses of the Latemar [6,7] that relate the meter-scale bedding to Milankovitch precession forcing.

\section{Reconsideration of Latemar cyclicity}

For $160 \mathrm{~m}$ of the Latemar UCF interval (CDL series, Fig. 2), Preto et al. [7] recognized four lithofacies (caliches/soils, supratidal flat, restricted subtidal lagoon, open subtidal lagoon) and ranked them according to relative water depth. A frequency power spectrum of the depth-rank CDL series with respect to meters of section, that is, with no tuning and assuming that to first-order stratigraphic thickness is a linear proxy of time, was shown by Preto et al. [7] (Part 2 of supplemental information, GSA Data Repository) and is reproduced in Fig. 4. Preto et al. [7] assigned to precession (a phase with an assumed period of 21.7 k.y.) a small, hardly distinguishable peak within a broad band of weak spectral power at around the average observed Latemar bedding thickness of $\sim 0.87 \mathrm{~m}$ (labeled as P1 in Fig. 4) and tuned the depth-rank series accordingly to derive an apparent age spectrum. This implies an average sediment accumulation rate of about $45 \mathrm{~m} / \mathrm{m}$.y. However, the most prominent spectral peak in the untuned frequency analysis is centered within error resolution at $\sim 10 \mathrm{~m}(0.1$ cycles $/ \mathrm{m}$, labeled B in Fig. 4). Interestingly, Egenhoff et al. [5] describe discrete tepee horizons just below the LCF and exposure horizons in the MTF and UTF, which bracket the CDL series (Fig. 2), as occurring about every $10 \mathrm{~m}$, suggesting that variation at about this wavelength is an important feature of the cyclicity over much of the section. According to Preto et al. [7], this spectral peak would correspond to a transient component with an apparent periodicity of $200 \mathrm{k} . \mathrm{y}$., which is not an obvious feature of Milankovitch theory. According to us, this shortest prominent spectral component more likely

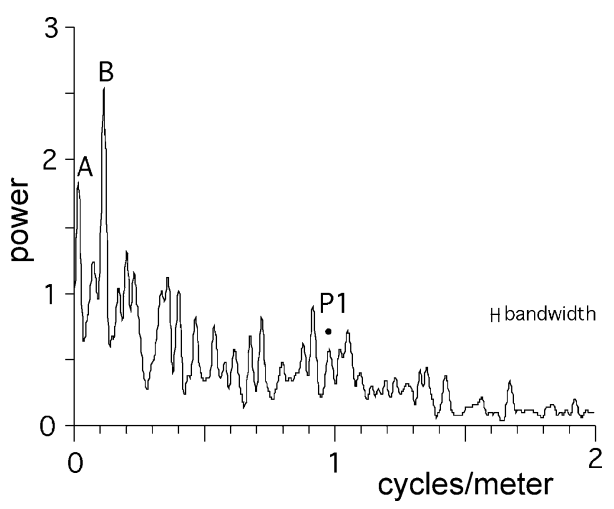

Fig. 4. A Blackman-Tukey power spectrum of the depth-rank CDL series (see Fig. 2 for stratigraphic range) with respect to meters of section (i.e., with no tuning and assuming that stratigraphic thickness is a linear first-order proxy of time) from data and recipe in Preto et al. [7] (Part 2 of supplemental information, GSA Data Repository) and which closely matches a multitaper power spectrum of the same data shown by Preto et al. [7]. A small peak, labeled P1, was assigned to precession by Preto et al. [7]. We suggest that the most prominent spectral peak (labeled B) is more compatible with precession (and spectral peak A with short eccentricity) based on our evaluation of the overall chronostratigraphic constraints; this would place P1 within the millennial band of variations. 
represents the shortest (precessional) Milankovitch cycle. This would imply an average sediment accumulation rate of $\sim 500 \mathrm{~m} / \mathrm{m} . \mathrm{y}$., in substantial agreement with the U-Pb zircon dates and litho-, bio-, and magnetostratigraphic correlations described above.

The second most prominent peak in the untuned spectrum, centered within error resolution at $\sim 50 \mathrm{~m}$ (0.02 cycles/m, labeled A in Fig. 4), may thus correspond to the expected but in this case poorly resolved short ( $\sim 100$ k.y.) eccentricity cycle. In support of this interpretation, the line spectrogram for the UCF series in [7] (Part 2 of supplemental information, GSA Data Repository) shows evidence of modulation of the 0.1 cycle/m component at a $\sim 50$-m wavelength, with increases in harmonic amplitudes at around 40, 90, and $150 \mathrm{~m}$ in the CDL section. More speculatively, the previously unexplained larger-scale subdivision of the Latemar into alternating cyclic and tepee facies, which also seems to be reflected in broad changes in bedding thickness (Fig. 5 in [10]), may be related to the long ( 400 k.y.) eccentricity cycle, which would imply a total duration of $\sim 800 \mathrm{k}$.y. for the LCF-MTF-UCFUTF Latemar cyclic succession.

An immediate consequence of our interpretation is that the visually obvious meter-scale bedding in the Latemar does not reflect precessional forcing but instead must lie in the sub-Milankovitch (millennial) band of variation, as previously suggested by Brack et al. [2]. Zühlke et al. [10] reached a similar conclusion more recently, using new bedding thickness data for the entire cyclic succession. They suggested that the basic shallowing-upward bedding in the Latemar represents cyclicity with an average period of 4.2 k.y. by assuming there was a $4-5: 1$ bundling with precession while staying within the analytical error limits of the available $\mathrm{U}-\mathrm{Pb}$ dating of volcanoclastic layers in the Latemar [9]. In our age model, the average bedding thickness of $0.87 \mathrm{~m}$ [7] would correspond to only $\sim 1.7 \mathrm{k} . \mathrm{y}$., which is closer to the average of about 2.2 k.y. per bed based on the mean $\mathrm{U}-\mathrm{Pb}$ dates $[9,10]$ with no assumption about any bundling relationship. In fact, it is difficult to show that the meter-scale bedding is actually metronomic, although bedding thickness was the fundamental unit for analysis by Zühlke et al. [10] whereas the depth-rank series analyzed by Preto et al. [7] included on average less than 3 depth-rank estimates per meter (472 points for $160 \mathrm{~m}$ of section), which is inadequate to establish periodicity with any degree of confidence at the meter scale. A further limitation at this level of resolution is that the exposure surfaces within the supratidal lithofacies defined by Preto et al. [7] and that often define the meter-scale bedding represent unknown and perhaps variable amounts of unrecorded time [4].

\section{Discussion}

The weak and poorly defined frequency spectral character of the meter-scale bedding variations might suggest that autocyclic processes governed the finescale growth of the carbonate platform. However, Egenhoff et al. [5] observed platform-wide subaerial exposure horizons and the involvement of subtidal facies in the tepee structures, which they argued indicate an allocyclic origin of the small-scale cycles. Various mechanisms have been proposed to account for the occurrence of cyclic sea-level oscillations in the apparent absence of continental ice sheets in the Triassic, including thermal expansion and contraction of the ocean water column or variable water storage in ground water and lakes (see discussion in [7]). One or a combination of these (and other) mechanisms remain open to explain periodicities at Milankovitch time scales in the Latemar, whether they occur down to the meter-scale bedding rhythmicity, as most recently proposed by Preto et al. [7], or only down to the 10$\mathrm{m}$ scale as we suggest.

Our estimated mean bedding duration of $\sim 1.7$ k.y. falls at an interesting timing within the orbital gap between annual and Milankovitch climate forcing. Sub-Milankovitch forcing of similar periodicity but of uncertain origin has been documented elsewhere and could conceivably contribute to the meter-scale cyclicity of the Latemar. In particular, climatic variations at regular intervals of about 1.5 k.y. occurred in the Late Pleistocene and Holocene and are thought to somehow be related to solar fluctuations [30]. An intriguing alternative mechanism that could potentially produce sea-level changes more directly is nonlinear interactions giving rise to low-frequency tidal forcing, which has been estimated to extend into the millennial (1.51.8 k.y.) waveband and shown that it can have sedimentary expressions [31-33]. The Latemar carbonate bank buildup, which is characterized by subtidal to 
peri- and supratidal deposits, would seem to be especially prone to biases in sedimentation resulting from processes like variable exposure and ocean water mixing that might be induced by long-term tidal amplitude variations. Indeed, variations in tide-generation at millennial time scales [31-33], in concert with tidal amplitude variations expected from Milankovitch astronomical forcing [34], could conceivably account for much of the overall cyclic depositional pattern of the Latemar platform.

We are not aware of any other Mesozoic platform carbonate setting that is comparably well constrained over a similar short time interval as the Latemar. Nevertheless, we would point out that the high sediment accumulation rate-short duration for the Latemar that is a consequence of our preferred age model does not conflict with the estimated growth potential of tropical carbonate factories [14]. Subsidence as indicated by South Alpine carbonate platforms was not uniform on a regional scale and consequently has a strong and locally variable tectonic component. In the Dolomites, this is evident from comparison of the thickness of coeval platform intervals; for example, net subsidence was higher by about $50 \%$ at Cernera when compared with Latemar [12]. Given such an active geodynamic setting, regular subsidence over a very long time span ( $\sim 10$ m.y.) that is implicit in the standard cycle stratigraphic interpretations of the Latemar $[4,6,7]$ seems less plausible than the higher but much more temporally confined subsidence rates resulting from age models for the Latemar, including ours, that adhere more closely to the $\mathrm{U}-\mathrm{Pb}$ dating $[2,8-10]$. We hesitate to make broad generalizations about the nature of cyclicity in other carbonate platforms, such as the classic Lofer cycles of the Upper Triassic Dachstein platform [35-37], in the general absence of independent age constraints that are essential to test Milankovitch or other periodicities that may be assumed or inferred from cycle stratigraphic analyses.

\section{Acknowledgements}

We thank L. Lanci for contributing insights into frequency analysis of the Latemar cyclic sequence, J. Sedlacek and F. Maurer for assistance in the fieldwork, and F. Hilgen and L. Hinnov for constructive critical comments on the manuscript. LamontDoherty Earth Observatory contribution \#6672.

\section{References}

[1] M. Gaetani, E. Fois, F. Jadoul, A. Nicora, Nature and evolution of the Middle Triassic carbonate buildups in the Dolomites (Italy), Mar. Geol. 44 (1981) 25-57.

[2] P. Brack, R. Mundil, F. Oberli, M. Meier, H. Rieber, Biostratigraphic and radiometric age data question the Milankovitch characteristics of the Latemar cycles (Southern Alps, Italy), Geology 24 (1996) 371-375.

[3] J.E.T. Channell, F. Horvath, The African/Adriatic promontory as a palaeogeographical premise for Alpine orogeny and plate movements in the Carpatho-Balkan region, Tectonophysics 35 (1976) $71-101$.

[4] R.K. Goldhammer, P.A. Dunn, L.A. Hardie, High frequency glacio-eustatic sealevel oscillations with Milankovitch characteristics recorded in Middle Triassic platform carbonates in northern Italy, Am. J. Sci. 287 (1987) 853-892.

[5] S.O. Egenhoff, A. Peterhänsel, T. Bechstädt, R. Zühlke, J. Grötsch, Facies architecture of an isolated carbonate platform: tracing the cycles of the Latemar (Middle Triassic, northern Italy), Sedimentology 46 (1999) 893-912.

[6] L.A. Hinnov, R.K. Goldhammer, Spectral analysis of the Middle Triassic latemar limestone, J. Sedimen. Petrol. 61 (1991) 1173-1193.

[7] N. Preto, L.A. Hinnov, L.A. Hardie, V. De Zanche, Middle Triassic orbital signature recorded in the shallow-marine Latemar carbonate buildup (Dolomites, Italy), Geology 29 (2001) 1123-1126.

[8] R. Mundil, P. Brack, M. Meier, H. Rieber, F. Oberli, High resolution $\mathrm{Uã} \mathrm{Pb}$ dating of Middle Triassic volcaniclastics: time-scale calibration and verification of tuning parameters for carbonate sedimentation, Earth. Planet. Sci. Lett. 141 (1996) $137-151$.

[9] R. Mundil, R. Zühlke, T. Bechstädt, A. Peterhänsel, S.O. Egenhoff, F. Oberli, M. Meier, P. Brack, H. Rieber, Cyclicities in Triassic platform carbonates: synchronizing radio-isotopic and orbital clocks, Terra Nova 15 (2003) 81-87.

[10] R. Zühlke, T. Bechstädt, R. Mundil, Sub-Milankovitch and Milanovitch forcing on a model Mesozoic carbonate platform - the Latemar (Middle Triassic, Italy), Terra Nova 15 (2003) 69-80.

[11] F. Maurer, Growth mode of Middle Triassic carbonate platforms in the Western Dolomites (Southern Alps, Italy), Sediment. Geol. 134 (2000) 275-286.

[12] P. Brack, G. Muttoni, High-resolution magnetostratigraphic and lithostratigraphic correlations in Middle Triassic pelagic carbonates from the Dolomites (northern Italy), Palaeogeogr. Palaeoclimatol. Palaeoecol. 161 (2000) 361-380.

[13] G. Muttoni, A. Nicora, P. Brack, D.V. Kent, Integrated Anisian-Ladinian boundary chronology, Palaeogeogr. Palaeoclimatol. Palaeoecol. 208 (2004) 85-102. 
[14] W. Schlager, Scaling of sedimentation rates and drowning of reefs and carbonate platforms, Geology 27 (1999) 183-186.

[15] W. Schlager, Benthic carbonate factories of the Phanerozoic, Int. J. Earth Sci. 92 (2003) 445-464.

[16] P. Mietto, S. Manfrin, N. Preto, L. Krystyn, G. Roghi, Proposal of the global stratigraphic section and point (GSSP) for the base of the Ladinian Stage (Middle Triassic), Albertiana 28 (2003) 26-34.

[17] Y. Gallet, J. Besse, L. Krystyn, J. Marcoux, H. Theveniaut, Magnetostratigraphy of the Late Triassic Bolucektasi Tepe section (southwestern Turkey): implications for changes in magnetic reversal frequency, Phys. Earth Planet. Inter. 73 (1992) 85-108.

[18] W. Lowrie, Identification of ferromagnetic minerals in a rock by coercivity and unblocking temperature properties, Geophys. Res. Lett. 17 (1990) 159-162.

[19] G. Muttoni, D.V. Kent, J.E.T. Channell, Evolution of Pangea: paleomagnetic constraints from the Southern Alps, Italy, Earth Planet. Sci. Lett. 140 (1996) 97-112.

[20] S. Vardabasso, Carta geologica del territorio eruttivo di Predazzo e Monzoni nelle Dolomiti di Fiemme e Fassa. A colori alla scala 1:25000, R. Scuola d'Ingeneria, Padova, 1930.

[21] P. Brack, R. Mundil, F. Oberli, M. Meier, H. Rieber, Biostratigraphic and radiometric age data question the Milankovitch characteristics of the Latemar cycle (Southern Alps, Italy): comment and reply: reply, Geology 25 (1997) 471-472.

[22] E.N. Wilson, L.A. Hardie, O.M. Phillips, Dolomitization front geometry, fluid flow patterns, and the origin of massive dolomite: the Triassic Latemar buildup, northern Italy, Am. J. Sci. 290 (1990) 741-796.

[23] F.M. Gradstein, F.P. Agterberg, J.G. Ogg, J. Hardenbol, P.V. Veen, J. Thierry, Z. Huang, A Triassic, Jurassic and Cretaceous time scale, SEPM Spec. Publ. 54 (1995) 95-126.

[24] Y. Gallet, L. Krystyn, J. Besse, J. Marcoux, Improving the Upper Triassic numerical tme scale from cross-correlation between Tethyan marine sections and the continental Newark basin sequence, Earth. Planet. Sci. Lett. 212 (2003) $255-261$.

[25] T.J. Algeo, Geomagnetic polarity bias patterns through the Phanerozoic, J. Geophys. Res. 101 (1996) 2785-2814.

[26] H.P. Johnson, D. Van Patten, M.A. Tivey, W.W. Sager, Geomagnetic polarity reversal rate for the Phanerozoic, Geophys. Res. Lett. 22 (1995) 231-234.
[27] G. Muttoni, M. Gaetani, K. Budurov, I. Zagorchev, E. Trifonova, D. Ivanova, L. Petrounova, W. Lowrie, Middle Triassic paleomagnetic data from northern Bulgaria: constraints on Tethyan magnetostratigraphy and paleogeography, Palaeogeogr. Palaeoclimatol. Palaeoecol. 160 (2000) 223-237.

[28] L. Krystyn, Das Epidaurus-Profil (Griechenland)-ein Beitrag zur Conodonten-Standardzonierung des tethyalen Ladin und Unterkarn, in: H. Zapfe (Ed.), Neue Beiträge zur Biostratigraphie der Tethys Trias, Schriftenreihe der erdwissenschaftlichen Kommission der österreichischen Akademie der Wissenschaften, vol. 5, 1983, pp. 231-258.

[29] N.J. Silberling, K.M. Nichols, Middle Triassic molluscan fossils of biostratigraphic significance from the Humboldt Range, Northwestern Nevada, U.S. Geol. Surv. Prof. Pap. 1207 (1982) 1-77.

[30] G. Bond, W. Showers, M. Cheseby, R. Lotti, P. Almasi, P. deMenocal, P. Priore, H. Cullen, I. Hajdas, G. Bonani, A pervasive millennial-scale cycle in North Atlantic Holocene and glacial climates, Science 278 (1997) 1257-1266.

[31] W. Munk, M. Dzxieciuch, S. Jayne, Milliennial climate variability: is there a tidal connection? J. Climate 15 (2002) $370-385$.

[32] C.D. Keeling, T.P. Whorf, The 1800 -year oceanic tidal cycle: a possible cause of rapid climate change, Proc. Nat. Acad. Sci. 97 (2000) 3814-3819.

[33] W.H. Berger, U. von Rad, Decadal to millennial cyclicity in varves and turbidites from the Arabian Sea: hypothesis of tidal origin, Glob. Planet. Change 34 (2002) 313-325.

[34] P.L. de Boer, Orbitally forced long-term variations of the astronomical tide and their role in the generation of Milankovitch and sub-Milankovitch cycles, in: B. D'Argenio, A.G. Fisher, I. Premoli Silva, H. Weissert (Eds.), Multidisciplinary Approach to Cyclostratigraphy, SEPM Society for Sedimentary Geology, Sorrento, 2001, abstract.

[35] A.G. Fischer, The Lofer cyclothems of the Alpine Triassic, Bull. Kansas Geol. Surv. 169 (1964) 107-149.

[36] W. Schwarzacher, J. Haas, Comparative statistical analysis of some Hungarian and Austrian Upper Triassic peritidal carbonate sequences, Acta Geol. Hung. 29 (1986) 175-196.

[37] A. Balog, J. Haas, J.F. Read, C. Coruh, Shallow marine record of orbitally forced cyclicity in a late Triassic carbonate platform, Hungary, J. Sediment. Res. 67 (1997) 661-675. 